\title{
PERSEPSI WAJIB PAJAK ORANG PRIBADI PADA TINGKAT KEPATUHAN ATAS PELAKSANAAN SELF ASSESSMENT SYSTEM DAN PENGARUHNYA TERHADAP TINDAKAN PENYELUNDUPAN PAJAK (TAX EVASION): STUDI PADA KANTOR PELAYANAN PAJAK PRATAMA SLEMAN YOGYAKARTA
}

\author{
Indah Puspitasari \\ Dewi Kusuma Wardani* \\ Program Studi Akuntansi Fakultas Ekonomi \\ Universitas Sarjanawiyata Tamansiswa \\ *E-mail: d3wi_kusuma@yahoo.co.id
}

\begin{abstract}
This study aimes to determine whether the perception of individual taxpayer compliance level for the implementation of self-assessment system tax evasion. The research was conducted by distributing questionnaires to individual taxpayers who are in the Kantor Pelayanan Pajak Pratama Sleman Yogyakarta (Tax Office Primary Sleman Yogyakarta).

This research is a quantitative study. Sampling method is convinience sampling. Is sampling that is the distributed 70 quesionare, three of the respondents did not fill and 2 did not full completed. So, obtained data from 65 respondents. We used linear regression analysis with SPSS for Windows 17.00.

We found that the perception of individual taxpayer compliance level for the implementation of self-assessment system negatively affect (tax evasion). The coesionare correlation coefficient is -0.547. It indicates that there is a moderate or fairly between individual taxpayer perception on the level of compliance on the implementation of selfassessment system for tax evasion. Negative direction indicates that the higher the perception of individual taxpayer compliance level for the implementation of self-assessment system, the lower tax evasion, or vise versa.
\end{abstract}

Keywords: Perception of taxpayer compliance level for the implementation of selfassessment system, tax evasion.

\section{PENDAHULUAN}

Indonesia merupakan salah satu negara yang membutuhkan aliran dana untuk proses menuju ke negara maju melalui pembangunan. Sumber pendapatan negara yang mampu untuk membiayai proses pembangunan tersebut salah satunya berasal dari sektor pajak. Menurut Undang-Undang Nomor 28 Tahun 2007, pajak merupakan kontribusi wajib kepada negara yang terutang oleh orang pribadi atau badan yang bersifat memaksa berdasarkan undangundang dengan tidak mendapatkan imbalan secara langsung dan digunakan untuk keperluan negara bagi sebesar-besarnya kemakmuran rakyat (Siahaan, 2010:34). Maka dari itu semua masyarakat yang menurut ketentuan perundang-undangan termasuk wajib pajak orang pribadi harus membayar pajak sesuai dengan kewajibannya.

Kegiatan pemerintah untuk memenuhi kebutuhan negara dan masyarakat semakin meningkat. Hal ini diikuti besarnya jumlah dana yang semakin meningkat guna untuk pembiayaan pengeluaran pembangunan. Pemerintah dituntut untuk mencari sumber penerimaan negara untuk mencukupi 
kebutuhan pengeluaran tersebut. Salah satu sumber penerimaan negara yang berasal dari pajak akan dituangkan dalam Anggaran Pendapatan Belanja Negara (APBN) (Siahaan, 2010:20-21).

Pajak merupakan alat bagi pemerintah untuk mencapai tujuan dengan mendapatkan penerimaan baik yang bersifat langsung maupun tidak langsung dari masyarakat guna membiayai pengeluaran rutin serta pembangunan nasional dan ekonomi masyarakat. Pajak sendiri berfungsi sebagai alat untuk mengisi kas negara (budgetair) dan sebagai alat pemerintah untuk mengatur rakyatnya melalui kebijakan fiskal yang ditetapkan (regulered) (Suwandhi, 2010:1).

Rakyat berkewajiban untuk membayar pajak, namun demikian di Indonesia masih banyak kasus tentang penggelapan pajak (tax evasion) seperti yang dilakukan PT Asian Agri Group (AAG). Dalam kasus ini, Direktorat Jendral Pajak Kementerian Keuangan menagih utang pajak ke Asian Agri Group sebesar 1,29 triliun. Nilai tersebut masih ditambah denda pajak 604 miliar. Angka tersebut merupakan $48 \%$ dari total penggelapan pajak yang dilakukan Asian Agri Group.

Adanya kasus penggelapan pajak tersebut akan mempengaruhi berbagai pihak terutama wajib pajak orang pribadi atas kewajibannya. Mereka akan berpikiran apabila perusahaan besar mampu menggelapkan pajak dengan jumlahnya miliaran maka wajib pajak lainnya juga dapat menggelapkan pajak. Hal seperti ini akan selalu muncul dipikiran wajib pajak apabila tidak segera diatasi. Penggelapan pajak merupakan pertanda kekurangberhasilan pemungutan pajak suatu negara sehingga membuat tingkat kepatuhan kewajiban perpajakan semakin rendah, terutama oleh wajib pajak orang pribadi.

Salah satu elemen penting yang menunjang keberhasilan pemungutan pajak suatu negara adalah sistem pemungutan pajak. Secara umum terdapat tiga sistem pemungutan pajak, yaitu official assessment system, self assessment system dan withholding system. Seiring dengan berjalannya waktu, sejak adanya reformasi di bidang perpajakan tahun 1984, Indonesia mulai menerapkan pemungutan pajak dengan self assessment system. Dalam sistem ini, wajib pajak dituntut untuk berperan aktif, mulai dari mendaftar diri sebagai wajib pajak, mengisi SPT (Surat Pemberitahuan), menghitung besarnya pajak yang terutang, dan menyetorkan kewajibannya (Suminarsasi, 2010:3).

Dalam self assessment system pemberdayaan masyarakat adalah hal yang pokok, dimana prinsip itikad baik merupakan tuntunan moral menyelenggarakan pembukuan untuk keperluan pajak Kartawan (2002). Tujuan dari adanya reformasi perpajakan tersebut antara lain : Pertama, meningkatkan kualitas pelayanan kepada wajib pajak sebagai sumber aliran dana untuk mengisi kas negara. Kedua, menekan terjadinya tindakan penyelundupan pajak (tax evasion) oleh wajib pajak. Ketiga, meningkatkan kepatuhan bagi wajib pajak dalam penyelenggaraan kewajiban perpajakannya. Keempat, menerapkan konsep good governance, adanya transparansi, responsibility, keadilan dan akuntabilitas dalam meningkatkan kinerja Instansi pajak, sekaligus publikasi jelasnya pos penggunaan pengeluaran dana pajak. Kelima, meningkatkan penegakan hukum pajak, pengawasan yang tinggi dalam pelaksanaan administrasi pajak, baik kepada fiskus maupun wajib pajak (Rahayu, 2009:99).

Pelaksanaan self assessment system dalam sistem pemungutan pajak di Indonesia memberi kepercayaan kepada wajib pajak dalam melaksanakan kewajiban maupun hak perpajakannya, seperti menghitung, membayar, dan melaporkan kewajiban pajaknya melalui surat pemberitahuan (SPT). Sistem ini menyebabkan kebenaran pembayaran pajak tergantung pada kejujuran dan kepatuhan wajib pajak itu sendiri dalam melaporkan kewajiban perpajakanya (Pangestu, 2011:2)

Kepatuhan pajak yang dimaksud adalah terkait dengan bagaimana 
melaporkan semua informasi yang diperlukan tepat pada waktunya, mengisi secara benar jumlah pajak terutang, dan membayar pajak pada waktunya. Dari tujuan tersebut diketahui bahwa pada awalnya, pelaksanaan self assessment sytem dimaksudkan untuk meningkatkan kepatuhan pajak dan menekan terjadinya penyelundupan pajak. Seandainya kepatuhan masyarakat semakin tinggi maka penerimaan pajak akan menjadi optimal. Sebaliknya jika kepatuhan masyarakat masih rendah akan membuat kesempatan wajib pajak untuk melakukan menyelundupkan pajak (Pangestu, 2011:2). Masalah kepatuhan wajib pajak adalah masalah penting di seluruh dunia, baik bagi Negara maju maupun di Negara berkembang, karena jika wajib pajak tidak patuh maka akan menimbulkan keinginan untuk melakukan tindakan penghindaran pajak, pengelakan, penyelundupan dan pelalaian pajak (Putra, 2012:14)

Adanya tindakan penyelundupan pajak yang terjadi akan membuat negara mengalami kerugian yang sangat besar. Banyak sektor pengeluaran negara tentunya mengalami hambatan akibat tidak tersedianya dana yang siap digunakan. Penyelundupan pajak harus sesegera mungkin diatasi untuk mencegah makin menjamurnya tindakan penyelundupan pajak (tax evasion). Salah satunya adalah dengan peningkatan kepatuhan wajib pajak atas pelaksanaan self assessment system.

Berdasarkan uraian tersebut, penulis tertarik untuk melakukan penelitian mengenai masalah tersebut dengan judul “ Persepsi wajib pajak orang pribadi pada tingkat kepatuhan atas pelaksanaan self assessment system dan pengaruhnya terhadap penyelundupan pajak (tax evasion)

Permasalahan dalam penelitian ini adalah bagaimana hubungan persepsi wajib pajak orang pribadi pada tingkat kepatuhan wajib pajak atas pelaksanaan self assessment system terhadap tindakan penyelundupan pajak (tax evasion)? Penelitian ini bertujuan untuk mengetahui apakah persepsi wajib pajak orang pribadi pada tingkat kepatuhan atas pelaksanaan self assessment system berpengaruh terhadap tindakan penyelundupan pajak (tax evasion).

\section{KERANGKA TEORITIS DAN PENGEMBANGAN HIPOTESIS \\ Penyelundupan Pajak}

Mortenson dalam Zain (2007) penyelundupan pajak berbeda dengan penghindaran pajak. Penyelundupan pajak adalah usaha yang tidak dapat dibenarkan berkenaan dengan kegiatan wajib pajak untuk lari atau menghindarkan diri dari pengenaan pajak. Sedangkan penghindaran pajak berkenaan dengan pengaturan sesuatu peristiwa sedemikian rupa untuk meminimkan atau menghilangkan beban pajak dengan memperhatikan ada atau tidaknya akibat-akibat pajak yang ditimbulkannnya.

Penyelundupan pajak merupakan kecurangan dan penggelapan dalam segala bentuknya seperti tidak menyampaikan SPT, tidak dapat memenuhi kewajiban menyetorkan pajak-pajak yang telah dipotong atau yang telah dipungut, tidak mendaftarkan diri dan menyalahgunakaan Nomor Pokok Wajib Pajak (NPWP). Hal utama yang menjadi salah satu alasan wajib pajak melakukan tindakan penyelundupan pajak (tax evasion) adalah adanya kebutuhan dasar manusia dalam memenuhi kebutuhan pokok hidupnya. Rendahnya tingkat kepatuhan wajib pajak atas kewajiban perpajakannya akan menyebabkan kurang optimalnya penerimaan pajak.

\section{Pelaksanaan self assessment system}

Prastiwi (2011) menjelaskan bahwa self assessment system merupakan suatu sistem yang memberikan kepercayaan dan tanggung jawab kepada wajib pajak untuk menghitung, memperhitungkan, dan membayar sendiri jumlah pajak yang terutang sesuai dengan ketentuan perpajakan yang berlaku. Wajib pajak diwajibkan untuk melaporkan secara teratur jumlah pajak yang terutang dan telah dibayar sebagaimana ditentukan dalam peraturan perpajakan. 
Pelaksanaan self assessment system di Indonesia masih banyak menimbulkan masalah mulai dari pendaftaran NPWP hingga pelaporan SPT. Kesulitan yang timbul atau terjadi diantaranya adalah menghitung pajak merupakan hal yang sangat sering dikeluhkan oleh masyarakat bila berhubungan dengan kantor pajak. Masyarakat merasakan bahwa mereka tidak tahu harus berbuat apa untuk melakukan kewajibannya karena tidak mempunyai pengetahuan yang cukup tentang perpajakan.

\section{Persepsi Wajib Pajak Orang Pribadi pada Tingkat Kepatuhan atas Pelaksanaan Self Assessment System .}

Rambe (2009) menyatakan bahwa wajib pajak patuh adalah wajib pajak yang memenuhi beberapa kriteria yaitu, wajib pajak tepat waktu dalam menyampaikan Surat Pemberitahuan (SPT), wajib pajak tidak mempunyai tunggakan pajak kecuali telah memperoleh izin untuk mengangsur atau menunda pembayaran pajaknya, serta wajib pajak tidak pernah dijatuhi hukuman karena melakukan tindak pidana dibidang perpajakan.

Berlakunya self assessment system di Indonesia menunjang besarnya peran wajib pajak dalam menentukan besarnya penerimaan negara dari sektor pajak yang didukung oleh kepatuhan pajak (tax compliance). Hal tersebut dapat disimpulkan bahwa kepatuhan pajak merupakan pelaksanaan atas kewajiban untuk menyetor dan melaporkan pajak yang terutang sesuai dengan peraturan perpajakan. Kepatuhan yang diharapkan dengan self assessment system adalah kepatuhan sukarela (voluntary compliance) bukan kepatuhan yang dipaksakan (compulsary compliance). Meningkatkan kepatuhan sukarela dari wajib pajak, diperlukan keadilan dan keterbukaan dalam menerapkan peraturan perpajakan, kesederhanaan peraturan dan prosedur perpajakan serta pelayanan yang baik dan cepat bagi wajib pajak (Rambe, 2009).

\section{Pengembangan Hipotesis}

Suwandhi (2010) melakukan penelitian tentang persepsi wajib pajak orang pribadi atas pelaksanaan self assessment system dalam kaitannya dengan tax evasion studi kasus pada Kantor Pelayanan Pajak Pratama Bandung Cibeunying. Variabel yang digunakan dalam penelitian Suwandhi (2010) adalah persepsi wajib pajak orang pribadi atas pelaksanaan self assessment system sebagai variabel independent, sedangkan tindakan penyelundupan pajak (tax evasion) sebagai variabel dependent. Hasil penelitian ini adalah bahwa persepsi wajib pajak atas pelaksanaan self assessment system berkaitan signifikan dengan tindakan tax evasion.

Semakin tinggi tingkat kebenaran menghitung dan memperhitungkan, ketepatan menyetor, serta mengisi dan memasukkan SPT wajib pajak, maka akan semakin tinggi juga tingkat kepatuhan wajib pajak dalam melaksanakan dan memenuhi kewajiban perpajakannya. Selain itu, jika wajib pajak mampu bersikap jujur dan patuh dalam pelaporan penghasilan terutangnya, maka wajib pajak tersebut tergolong orang yang telah mematuhi adanya sistem penerapan self assessment system, serta dengan adanya hal tersebut proses perpajakan akan berjalan dengan baik dan penerimaan pajak negara bertambah optimal. Sebaliknya, jika sistem self assessment system banyak disalahgunakan dan banyak menimbulkan masalah yang pada akhirnya wajib pajak melakukan tindakan penggelapan pajak (tax evasion) yang mengakibatkan penerimaan pajak akan semakin rendah bahkan bisa jadi kemungkinan tidak bisa menutup pengeluaran rutin Negara.

Aparatur perpajakan berperan sebagai pembina, pembimbing dan pengawas pelaksanaan kewajiban yang dilakukan oleh wajib pajak. Oleh karena itu, sistem ini akan berjalan dengan baik apabila masyarakat memiliki tingkat kesadaran perpajakan secara sukarela (voluntary tax compliance) yang tinggi. Apabila tingkat kesadaran mereka masih rendah maka akan 
menimbulkan masalah, yaitu penggelapan pajak (tax evasion). Penggelapan pajak (tax evasion) merupakan usaha yang digunakan oleh wajib pajak untuk mengelak dari kewajiban yang sesungguhnya, dan merupakan perbuatan yang melanggar undang-undang pajak, misalnya wajib pajak tidak melaporkan pendapatan yang sebenarnya (Suminarsasi, 2010:3). Hipotesis yang dapat diambil dalam penelitian ini adalah:

\section{Ha: Persepsi wajib pajak orang pribadi pada tingkat kepatuhan atas pelaksanaan self assessment system berpengaruh negatif terhadap tindakan penyelundupan pajak (tax evasion).}

\section{DESAIN PENELITIAN \\ Populasi}

Populasi yang digunakan dalam penelitian ini adalah wajib pajak yang terdaftar pada Kantor Pelayanan Pajak Pratama Sleman Yogyakarta.

\section{Sampel}

Sampel yang digunakan dalam penelitian ini adalah wajib pajak orang pribadi yang berada di Kantor Pelayanan Pajak Pratama Sleman Yogyakarta pada hari Selasa-Rabu 19-20 Februari 2013. Sampel yang disebarkan dalam penelitian sebanyak 70 kuesioner. Dari hasil penyebaran kuesioner tersebut 3 responden hanya mengisi identitas, 2 responden tidak mengisi kuesioner penuh, maka 5 responden tersebut tidak digunakan dalam sampel. Jadi jumlah keseluruhan sampel yang digunakan dalam penelitian sebanyak 65 responden.

\section{Tempat Penelitian}

Lokasi atau tempat yang digunakan untuk penelitian adalah di Kantor Pelayanan Pajak Pratama Sleman Yogyakarta.

\section{Alat Analisis}

Alat analisis yang digunakan untuk menganalisis data adalah analisis deskriptif serta analisi regresi linier sederhana. Analisis deskriptif digunakan untuk menganalisis data berdasarkan jenis kelamin, profesi, pendidikan terakhir dan usia responden. Uji asumsi klasik yang terdiri dari uji heteroskedastisitas untuk menguji terjadinya kesamaan varian, serta uji normalitas untuk mengetahui distribusi kenormalan. Analisis korelasional untuk mengetahui hubungan antara persepsi wajib pajak orang pribadi pada tingkat kepatuhan atas pelaksanaan self assessment system dan pengaruhnya terhadap tindakan penyelundupan pajak (tax evasion).

\section{TEMUAN PENELITIAN}

\section{Uji Validitas dan Uji Reliabilitas}

Sebelum melakukan penelitian dilakukan pengujian terlebih dahulu uji awal atau pilot test dengan 30 sampel responden dan sasaran responden adalah Mahasiswa dan Dosen Universitas Sarjanawiyata Tamansiswa Fakultas Ekonomi pada SabtuMinggu 9-10 Februari 2013. Hasil pilot test uji validitas variabel $\mathrm{X}$ yaitu persespi wajib pajak orang pribadi pada tingkat kepatuhan atas pelaksanaan self assessment system dari 19 pernyataan 11 pernyataan valid dan 8 pernyataan tidak valid. Kedelapan pernyataan yang tidak valid tersebut dimodifikasi oleh peneliti dari beberapa masukan. Hasil uji reliabilitas 0,776 (78\%).

Serta hasil uji validitas variabel $\mathrm{Y}$ tindakan penyelundupan pajak (tax evasion) diketahui bahwa dari 13 pernyataan terdapat 8 pernyataan yang valid dan 5 pernyataan yang tidak valid. Kelima pernyataan yang tidak valid dimodifikasi oleh peneliti dari beberapa masukan. Sedangkan untuk uji hasil uji reliabilitas $\mathrm{Y}$ tindakan penyelundupan pajak (tax evasion) 0,791 (80\%). Dalam penelitian ini telah diperoleh hasil uji validitas dan relibilitas pada responden sebenarnya pada Kantor Pelayanan Pajak Pratama Sleman Yogyakarta Selasa-Rabu 19-20 Februari 2013.

Uji Validitas persepsi wajib pajak orang pribadi pada tingkat kepatuhan atas pelaksanaan self assessment system, menunjukkan bahwa semua pernyataan valid dan tidak ada yang gugur dengan signifikansinya sebesar 0,000 , dibawah 
koefisien $\alpha \leq 0,05(5 \%)$. Tingkat validitas dapat dijelaskan bahwa persepsi wajib pajak orang pribadi pada tingkat kepatuhan atas pelaksanaan self assessment system dari 18 item pernyataan, terdiri dari pernyataan nomor 1 sampai 18 tidak ada yang gugur dan semuanya valid. Sedangkan uji reliabilitasnya menggunakan Cronbach's Alpha sebesar 0,846 artinya persepsi wajib pajak orang pribadi pada tingkat kepatuhan atas pelaksanaan self assessment system memiliki nilai reliabilitas yang handal dan memadai.

Uji validitas dan reliabilitas yang terakhir adalah untuk uji item pernyataan dengan variabel tindakan penyelundupan pajak (tax evasion). Semua pernyataan valid dan signifikansi rata-rata sebesar 0.000 dibawah koefisien $\alpha \leq 0,05$ (5\%). Hal ini menunjukkan bahwa tindakan penyelundupan pajak (tax evasion) yang terdiri dari 13 item pernyataan, terdiri dari pernyataan nomor 19 sampai 31, tidak ada yang gugur dan semuanya valid. Nilai Cronbach's Alpha item pernyataan tindakan penyelundupan pajak (tax evasion) sebesar 0,801 artinya tindakan penyelundupan pajak (tax evasion) tersebut memiliki nilai reliabilitas yang handal dan memadai.

\section{Analisis Deskriptif}

Analisis deskriptif, digunakan untuk menjelaskan beberapa karasteristik responden dalam penelitian diantaranya:

1. Karakteristik responden berdasarkan jenis kelamin

Tabel 1

Karakteristik responden berdasarkan jenis kelamin

\begin{tabular}{lccc}
\hline Kategori & Frekuensi & Prosentase & $\begin{array}{c}\text { Prosentase } \\
\text { Kumulatif }\end{array}$ \\
\hline Pria & 49 & 75.4 & 75.4 \\
Wanita & 16 & 24.6 & 100.0 \\
Total & 65 & 100.0 & \\
\hline
\end{tabular}

Karakteristik responden berdasarkan jenis kelamin diketahui bahwa sebagian besar berjenis kelamin laki-laki sebanyak 49
$(75,4 \%)$ dan jenis kelamin perempuan sebanyak $16(24,6 \%)$.

2. Karakteristik responden berdasarkan profesi

Tabel 2

Karakteristik responden berdasarkan profesi

\begin{tabular}{lccc}
\hline \multicolumn{1}{c}{ Kategori } & Frekuensi & Prosentase & $\begin{array}{c}\text { ProsentaseKu } \\
\text { mulatif }\end{array}$ \\
\hline Tidak diketahui & 34 & $52 \%$ & 52 \\
Ternak & 2 & $3 \%$ & 55 \\
Dagang & 6 & $9 \%$ & 65 \\
Jasa & 18 & $28 \%$ & 92 \\
Suplier & 3 & $5 \%$ & 97 \\
Konsultan & 2 & $3 \%$ & 100 \\
Total & 65 & 100 & \\
\hline
\end{tabular}

Karakteristik responden berdasarkan profesi sebagian besar mayoritas tidak diketahui sebesar $34(52 \%)$ profesinya kemudian diikuti oleh bidang jasa 18 (28\%). 
3. Karakteristik responden berdasarkan pendidikan terakhir.

Tabel 3

\begin{tabular}{lccc}
\multicolumn{3}{c}{ Karaktersitik responden Pendidikan terakhir } \\
\hline \multicolumn{1}{c}{ Kategori } & Frekuensi & Prosentase & $\begin{array}{c}\text { Prosentase } \\
\text { Kumulatif }\end{array}$ \\
\hline Tidak diketahui & 7 & $11 \%$ & 11 \\
SLTA & 24 & $37 \%$ & 48 \\
D1 & 1 & $1 \%$ & 49 \\
D3 & 8 & $12 \%$ & 62 \\
S1 & 23 & $35 \%$ & 97 \\
S2 & 2 & $3 \%$ & 100 \\
Total & 65 & 100 & \\
\hline
\end{tabular}

Karakteristik responden berdasarkan pendidikan terakhir SLTA. Kemudian diikuti pendidikan terakhir dapat diketahui bahwa oleh responden yang menempuh jenjang $24(37 \%)$ responden menempuh jenjang pendidikan terakhir sebayak $23(35 \%)$.

4. Karakteristik responden berdasarkan usia

Tabel 4

Karakteristik responden berdasarkan usia

\begin{tabular}{lccc}
\hline \multicolumn{1}{c}{ Kategori } & Frekuensi & Prosentas & Prosentase Komulatif \\
\hline$<=30$ & 28 & 43.1 & 43.1 \\
$31-39$ & 14 & 21.5 & 64.6 \\
$40-49$ & 17 & 26.2 & 90.8 \\
$50+$ & 6 & 9.2 & 100.0 \\
Total & 65 & 100.0 & \\
\hline
\end{tabular}

Karakteristik responden berdasarkan usia dapat diketahui bahwa dibawah usia 30 tahun sebanyak $28 \quad(43,1 \%)$ selanjutnya responden berusia 40-49 sebanyak 17 $(26,2 \%)$.

Tabel 5

\section{Statistik Deskriptif}

Analisa statistik deskriptif didasarkan pada data wajib pajak yang terkumpul sebagai responden.

\section{Rekapitulasi data tingkat kepatuhan} wajib pajak atas pelaksanaan SAS

\begin{tabular}{cccccc}
\hline Interval & Frekuensi & $\mathbf{X}$ & $\mathbf{x}^{\mathbf{2}}$ & $\mathbf{f x}$ & $\mathbf{f x}^{2}$ \\
\hline $43-49$ & 7 & 46 & 2116 & 322 & 14812 \\
$50-56$ & 28 & 53 & 2809 & 1484 & 78652 \\
$57-63$ & 20 & 60 & 3600 & 1200 & 72000 \\
$67-72$ & 10 & 69 & 4761 & 690 & 47610 \\
\hline Total & 65 & & & $3696=\Sigma \mathrm{fx}$ & $213074=\sum \mathrm{fx}^{2}$ \\
\hline
\end{tabular}

Berdasarkan tabel tersebut dapat diketahui bahwa variabel persepsi wajib pajak orang pribadi pada tingkat kepatuhan atas pelaksanaan self assessment system memiliki nilai terendah 43 dan tertinggi 75. Berdasarkan hasil rekapitulasi data diketahui 


\section{JURNAL AKUNTANSI. VOL 1. NO.2 DESEMBER 2013}

besarnya mean (rata-rata) sebesar 56,86 dengan standar deviasi 6,70.

Tabel 6

Rekapitulasi data penyelundupan pajak

( Tax evasion)

\begin{tabular}{cccccc}
\hline Interval & $\mathbf{F}$ & $\mathbf{X}$ & $\mathbf{x}^{\mathbf{2}}$ & $\mathbf{F x}$ & $\mathbf{f x}^{\mathbf{2}}$ \\
\hline $13-16$ & 12 & 15 & 225 & 180 & 2700 \\
$17-20$ & 10 & 19 & 361 & 190 & 3610 \\
$21-24$ & 11 & 23 & 529 & 253 & 5819 \\
$25-31$ & 32 & 27 & 729 & 864 & 23328 \\
\hline Total & 65 & & & $1487=\mathrm{fx}$ & $35457=>\mathrm{fx}^{2}$ \\
\hline
\end{tabular}

Berdasarkan tabel tersebut dapat diketahui bahwa variabel tindakan penyelundupan pajak memiliki nilai terendah 13 dan tertinggi 31. Berdasarkan rekapitulasi data diketahui besarnya nilai mean (rata-rata) sebesar 22,88 dan standar deviasi sebesar 4,71 .

Sebagai acuan yang digunakan untuk mencari mean (rata-rata) dan standar deviasi dapat dilihat pada tabel statistik deskriptif sebagai berikut:

Tabel 7

Statistik diskriptif

\begin{tabular}{lccccc}
\hline & N & Minimum & Maximum & Mean & $\begin{array}{c}\text { Std. } \\
\text { Deviation }\end{array}$ \\
\hline Kepatuhan & $\mathbf{6 5}$ & $\mathbf{4 3 . 0 0}$ & $\mathbf{7 2 . 0 0}$ & $\mathbf{5 6 . 8 6}$ & $\mathbf{6 . 7 0}$ \\
tax evasion & 65 & 13.00 & 31.00 & 22.88 & 4.71 \\
Valid N (listwise) & 65 & & & & \\
\hline
\end{tabular}

Sumber : Analisa data dengan menggunakan SPSS

\section{Sebaran Frekuensi Data}

Analisis frekuensi untuk sebaran data berdasarkan kategori pengukuran untuk masing-masing variabel tingkat kepatuhan atas pelaksanaan self assessment system dan tindakan penyelundupan pajak (tax evasion).

Tabel 8

Kepatuhan atas pelaksanaan self assessment system

\begin{tabular}{lccc}
\hline Kategori & Rentang & Frekuensi & Persen \\
\hline Sangat tidak patuh & $43-49$ & 7 & $11 \%$ \\
Tidak patuh & $50-56$ & 28 & $43 \%$ \\
Patuh & $57-63$ & 20 & $31 \%$ \\
Sangat patuh & $67-72$ & 10 & $15 \%$ \\
Total & & 65 & $100 \%$ \\
\hline
\end{tabular}

Dari tabel tersebut dapat diketahui sebagian besar responden sebanyak 35 (54\%) dikatakan tidak patuh dan sangat tidak patuh atas pelaksanaan self assessment system selanjutnya untuk responden yang patuh dan sangat patuh atas pelaksanaan self assessment system sebanyak 30 (46\%). 
Tabel 9

Kemungkinan wajib pajak melakukan penyelundupan pajak (Tax Evasion)

\begin{tabular}{lccc}
\hline Kategori & Rentang & Frekuensi & Persen \\
\hline Sangat berpotensi & $13-16$ & 12 & $18 \%$ \\
Berpotensi & $17-20$ & 10 & $15 \%$ \\
Tidak berpotensi & $21-24$ & 11 & $17 \%$ \\
Sangat tidak berpotensi & $25-31$ & 32 & $49 \%$ \\
Total & & 65 & $100 \%$ \\
\hline
\end{tabular}

Tabel tersebut dapat diketahui sebagian besar responden sebanyak 43 (66\%) tidak berpotensi dan sangat tidak berpotensi untuk melakukan penyelundupan pajak (tax evasion) selanjutnya untuk responden yang berpotensi dan sangat berpotensi untuk melakukan penyelundupan pajak (tax evasion) sebanyak 22 (33\%).

\section{Uji Asumsi Klasik}

\section{Uji Heteroskedastisitas}

Diperoleh hasil penyebaran titik-titik secara acak dan tidak membentuk pola hal ini menunjukkan bahwa persepsi wajib pjak orang pribadi pada tingkat kepatuhan atas pelaksanaan self assessment system tidak memiliki nilai varian yang sama terhadap tindakan penyelundupan pajak (tax evasion).

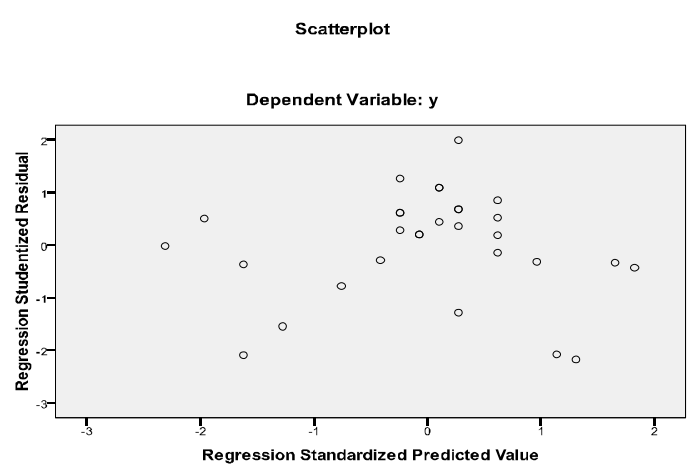

Uji Normalitas

Diperoleh hasil penyebaran titik-titik menyebar disekitar garis diagonal, sehingga tindakan penyelundupan pajak diprediksi rendah oleh persepsi wajib pajak orang pribadi pada tingkat kepatuhan atas pelaksanaan self assessment system.

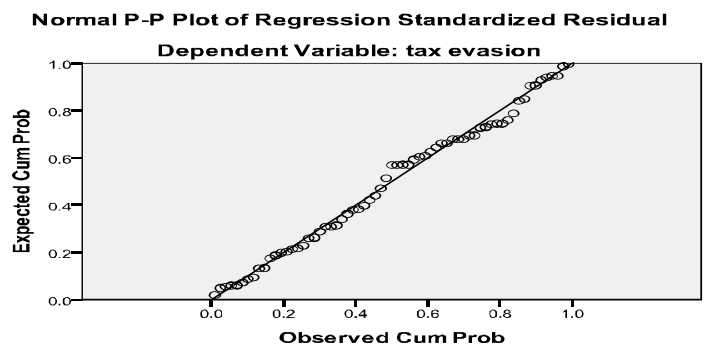

Analisis Korelasi

Hasil perhitungan korelasi adalah sebesar 0,547 artinya terdapat hubungan sedang atau cukup dan signifikan antara persepsi wajib pajak orang pribadi pada tingkat kepatuhan atas pelaksanaan self assessment system dan pengaruhnya terhadap tindakan penyelundupan pajak (tax evasion). Arah negatif menunjukkan semakin tinggi persepsi wajib pajak orang pribadi pada tingkat kepatuhan atas pelaksanaan self assessment system akan membuat tindakan penyelundupan pajak (tax evasion) semakin rendah begitu pula sebaliknya. Hal ini dapat dilihat pada tabel berikut :

Tabel 10

\section{Hasil perhitungan korelasi}

\begin{tabular}{llc}
\hline Variabel & & $\begin{array}{c}\text { tax evasion } \\
(\mathbf{y})\end{array}$ \\
\hline Kepatuhan atas & Pearson & $-.547^{*}$ \\
pelaksanaan self & Correlation & \\
$\begin{array}{l}\text { assessment system } \\
(\mathrm{x})\end{array}$ & Sig. (2-tailed) & .000 \\
\hline & $\mathrm{N}$ & 65 \\
\hline
\end{tabular}

*. Correlation is significant at the 0.05 level (2tailed).

\section{Analisis Regresi Linier Sederhana}

Analisis regresi linier sederhana dapat dilihat pada tabel dibawah ini dapat diketahui bahwa, $\mathrm{y}=45,05-0,396 \mathrm{x}$ nilai costanta (a) 45,054 terjadinya tindakan penyelundupan 
pajak (tax evasion) apabila tidak ada kepatuhan wajib pajak atas pelaksanaan self assessment system sebesar 45,054. Nilai koefisisen regresi $(\beta)$ sebesar $-0,396(0,40)$ akan ada penurunan terjadinya tindakan penyelundupan pajak (tax evasion) sebesar 40\% apabila tingkat kepatuhan wajib pajak atas pelaksanaan self assessment system naik sebesar $1 \%$. Tanda negatif koefisien regresi menunjukkan semakin tinggi persespi wajib pajak pada tigkat kepatuhan wajib pajak atas pelaksanaan self assessment system berdampak menurunya tindakan penyelundupan pajak (tax evasion).

\section{Tabel 11}

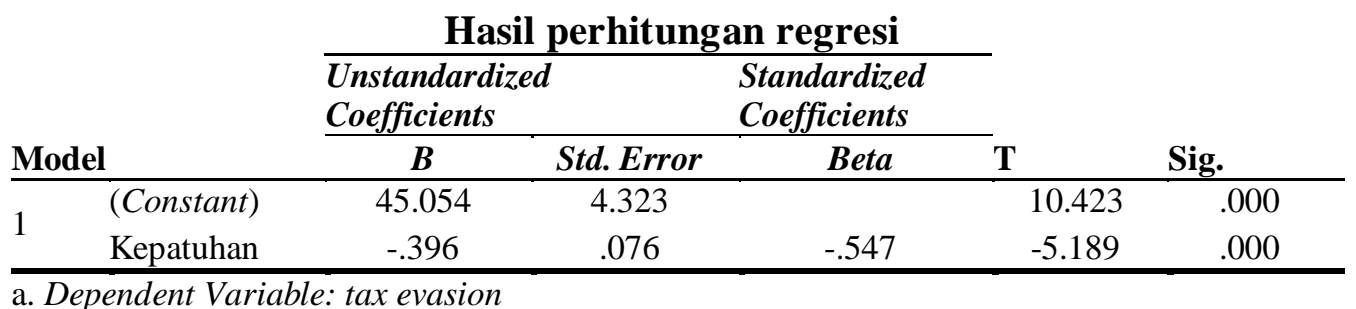

a. Dependent Variable: tax evasion

\section{Uji Hipotesis}

Diperoleh uji t besarnya $t_{\text {hitung }}$ sebesar 5,189 (lihat tabel perhitungan regresi) dan $\mathrm{t}_{\text {tabel }}-1,99$ (untuk $\alpha$ 0,05 dan $\mathrm{Df}=63$ (df=banyaknya sampel-variabel atau 65-2) diperoleh $t$ tabel sebesar -1.99 . Karena $t_{\text {hitung }}$ lebih besar dari $t_{\text {tabel }}$ maka Ha diterima dan Ho ditolak artinya bahwa terdapat pengaruh yang signifikan antara persepsi wajib pajak orang pribadi pada tingkat kepatuhan atas pelaksanaan self assessment system terhadap tindakan penyelundupan pajak (tax evasion).

\section{Koefisien Determinasi}

Diperoleh nilai R Square sebesar 0,299 (30\%) artinya bahwa persepsi wajib pajak orang pribadi pada tingkat kepatuhan atas pelaksanaan self assessment system mempengaruhi tindakan penyelundupan pajak (tax evasion) sebesar $30 \%$ sedangkan sisanya $70 \%$ disebabkan oleh variabel lain yang diteliti.

Hal ini dapat dibandingkan dengan adanya penelitian Suwandhi (2010) yang memperoleh koefisien determinasi sebesar $30 \%$. Berarti menunjukkan bahwa masih ada faktor lain sebesar $40 \%$ yang mempengaruhi tindakan penyelundupan pajak oleh wajib pajak selain dari variabel yang sedang diteliti dalam penelitian ini yaitu kurangnya kesadaran kewajiban wajib pajak, tarif pajak yang tinggi, serta pelayanan fiskus yang mengecewakan (Suwandhi:2010). Hasilnya dapat dilihat pada tabel berikut:

Tabel 12

Model Summary ${ }^{\mathbf{b}}$

\begin{tabular}{ccccc}
\hline Mode l & R & R Square & $\begin{array}{c}\text { Adjusted } \boldsymbol{R} \\
\text { Square }\end{array}$ & $\begin{array}{c}\text { Std. Error of the } \\
\text { Estimate }\end{array}$ \\
\hline 1 & $.547^{\mathrm{a}}$ & .299 & .288 & 4.17431 \\
\hline
\end{tabular}

a. Predictors: (Constant), Kepatuhan atas pelaksanaan self assessment system

b. Dependent Variable: tax evasion

Implikasi, Simpulan, Saran dan

\section{Keterbatasan}

\section{Simpulan}

Simpulan yang diperoleh dalam penelitian ini adalah persepsi wajib pajak orang pribadi pada tingkat kepatuhan atas pelaksanaan self assessement system dan pengaruhnya terhadap penyelundupan pajak (tax evasion) termasuk dalam kategori sedang atau cukup. Artinya adanya persepsi 
wajib pajak orang pribadi pada tingkat kepatuhan wajib pajak atas pelaksanaan self assessment system yang dimulai dari pendaftaran NPWP, perhitungan pajak, pelaporan dan penyetoran Surat Pemberitahuan oleh wajib pajak itu sendiri serta pelayanan dan pengawasan dari pihak fiskus belum maksimal baik.

Semakin tinggi persepsi wajib pajak orang pribadi pada tingkat kepatuhan wajib pajak pada Kantor Pelayanan Pajak Pratama Sleman Yogyakarta akan menjadikan penurunan kemungkinan wajib pajak melakukan tindakan penyelundupan pajak (tax evasion).

Berdasarkan hasil pengujian hipotesis diketahui bahwa tingkat kepatuhan atas pelaksanaan self assessment system berkaitan signifikan terhadap adanya tindakan penyelundupan pajak (tax evasion) pada Kantor Pelayanan Pajak Pratama Sleman Yogyakarta. Hubungan antara tingkat kepatuhan atas pelaksanaan self assessment system pengaruhnya terhadap penyelundupan pajak (tax evasion) juga dipengaruhi oleh variabel lain yang diteliti diantaranya adalah sistem perpajakan, kurangnya kesadaran masyarakat wajib pajak akan kewajiban perpajakannya, kondisi lingkungan, ekonomi dan sosial, tarif pajak yang tinggi serta pelayanan fiskus yang kadang mengecewakan.

\section{Implikasi}

Berdasarkan hasil penelitian yang telah dilakukan di Kantor Pelayanan Pajak Pratama Sleman Yogyakarta penelitian ini mempunyai kontribusi atau implikasi tentang persepsi wajib pajak orang pribadi pada tingkat kepatuhan atas pelaksanaan self assessment system terhadap tindakan penyelundupan pajak (tax evasion) menambah bukti penelitian bahwa terjadinya tindakan penyelundupan pajak (tax evasion) ini tidak hanya terbukti di Kantor Pelayanan Pajak Pratama Bandung Cibeunying tetapi juga terjadi di Kantor Pelayanan Pajak Pratma Sleman Yogyakarta.

KPP dapat melakukan pemeriksaan atau mengambil sampel pada wajib pajak yang tidak patuh terhadap self assessment system hal ini dapat membantu mengurangi pengeluaran untuk melakukan pemeriksaan dan dapat menjadi lebih baik lagi.

\section{Keterbatasan}

Penulis juga akan menjelaskan keterbatasan yang penulis miliki dalam proses melakukan penelitian, diantaranya dalam penelitian ini metode pengambilan sampel yang digunakan adalah convenience sampling, untuk pengambilan sampel secara nyaman dilakukan dengan memilih sampel bebas sekehendak perisetnya. Metode ini terlalu sederhana untuk digunakan dan terlalu lemah untuk digeneralisasikan.

Variabel yang digunakan peneliti dalam penelitian ini hanya dua variabel, masing-masing dependent dan independent, masih banyak variabel yang dapat dijelaskan dan digunakan untuk memperediksi tindakan penyelundupan pajak (tax evasion) sistem perpajakan, tindakan keadilan atau pelayanan fiskus.

\section{Saran}

Saran penulis ajukan dalam penelitian ini diantaranya adalah persepsi wajib pajak orang pribadi pada tingkat kepatuhan atas pelaksanaan self assessment system dan pengaruhnya terhadap penyelundupan (tax evasion) masih tergolong sedang atau cukup, sebaiknya perlu peningkatkan sosialisasi mengenai self assessment system, karena masih banyak wajib pajak yang kurang memperhatikan adanya tingkat kepatuhan atas pelaksanaan self assessment system serta agar wajib pajak lebih sadar dan patuh atas kewajiban perpajakannya.

Persepsi wajib pajak orang pribadi pada tingkat kepatuhan atas pelaksanaan self assessment system sangat memiliki pengaruh/hubungan yang sifgnifikan terhadap tindakan penyelundupan pajak ( $\operatorname{tax}$ evasion) untuk itu diharapkan Kantor Pelayanan Pajak Pratama Sleman Yogyakarta memberikan pengawasan yang lebih dalam pelaksanaan self assessment system, hal ini bertujuan untuk menekan banyaknya tindakan penyelundupan pajak 
(tax evasion) yang dilakukan oleh wajib pajak.

Metode pengumpulan sampel yang digunakan dalam penelitian ini adalah conviniance sampling, sifat sampel ini terlalu sederhana, untuk penelitian selanjutnya dapat digunakan teknik pengambilan sampel yang lain seperti random sampling atau purposive sampling.

Variabel yang digunakan dalam penelitian ini hanya dua variabel, satu variabel dependent dan satu lagi variabel independent, apabila penelitian ini digunakan lagi, variabel dalam penelitian ini bisa ditambah.

Kantor Pelayanan Pajak Pratama Sleman Yogyakarta dapat melakukan pemeriksaan dilakukan/difokuskan pada wajib pajak yang tidak patuh karena memiliki kecenderungan untuk melakukan tindakan penyelundupan pajak (Tax Evasion).

\section{Daftar Pustaka}

Aditya Rizky Putra, 2012." Efektifitas sanksi pidana bagi wajib pajak yang melanggar ketentuan undang-undang nomor 28 tahun 2007 tentang ketentuan umum dan tata cara perpajakan “. Skripsi S1 Ilmu Hukum Fakultas Hukum Universitas Pembangunan Nasional "Veteran" Jawa Timur. Diunduh Rabu 27 Februari 2013 pukul 06.01 WIB

Anas Sudjiono, 2010. “ Pengantar Statistik Pendidikan “. edisi pertama. Jakarta: Penerbit Rajawali

Ayu Ajeng Prastiwi, 2011. “Pemeriksaan pajak sebagai tindakan pengawasan atas pelaksanaan sistem self assessment

\section{Skripsi S1 Fakultas Ekonomi Thiverias Pembangunan Nasional" Veteran" Jawa Timur. Diunduh Sabtu Mei 2012 pukul 20.15 WIB}

Ferdyant Pangestu, 2011. "Analisis Faktorfaktor yang Berpengaruh Terhadap Tax Compliance penyetoran SPT Masa".
Skripsi S1 Fakultas Ekonomi Universitas Jendral Soedirman Purwokerto (diunduh Sabtu 19 Januari 2013 pukul 12.30 WIB)

Jatmiko Nugroho, 2006. “Pengaruh Sikap Wajib Pajak Pada Pelaksanaan Sanksi Denda, Pelayanan Fiskus dan Kesadaran Perpajakan Terhadap Kepatuhan Wajib Pajak (Studi di Semarang)". Tesis pada Pascasarjana Universitas Diponegoro Program Studi Magister Akuntansi. Diunduh 1 Maret 2013 pukul 05.50 WIB

Jonathan, Sarwono\&Tutty Martadireja, 2008. Riset Bisnis untuk Pengambilan Keputusan. edisi pertama. Yogyakarta: Penerbit Andi

Jogiyanto HM, 2008. Pedoman Survei Kuesioner. Yogyakarta. BPFE

Kartawan\&Dedi Kusmayadi, 2002. “ Pengaruh Persepsi Wajib Pajak Badan Mengenai Undang-undang Pajak Penghasilan terhadap Pelaksanaan Sistem Self Assessment pada BUMS dan BUMD Kantor Pelayanan Pajak Tasikmalaya". Tesis pada Pascasarjana Universitas Gunadarma Fakultas Ekonomi Universitas Siliwangi. Jurnal Ekonomi \& Bisnis No.2 Jilid 7, Tahun 2002. Diunduh Minggu 3 Juni 2012 pukul 19.50 WIB

Marihot Pahala Siahaan, 2010. Hukum Pajak Elementer Konsep Dasar Perpajakan Indonesia. Yogyakarta : Graha Ilmu

Pajak atas Pengenaan Pajak Penghasilan :Anteseden dan Konsekuensinya(Kajian empiris pada wajib pajak orang pribadi yang memiliki usaha dikota Kudus). Skripsi S1 Akuntansi Fakultas Ekonomi Universitas Diponengoro. Diunduh Kamis 28 Febriuari 2013 pukul 13.37 WIB. 
M.Zain, 2007. Manajemen Perpajakan. Jakarta : Salemba Empat.

Rahayu, 2009. "Skripsi persepsi wajib pajak orang pribadi atas pelaksanaan self assessment system dalam terkaitannya dengan tindakan tax evasion pada KPP X". Gudang makalah, skripsi dan tesis diunduh kamis 13 September 2012 pukul 06.15 WIB

Rambe, 2009." Pengaruh penerapan self assessment system terhadap tingkat kepatuhan wajib pajak badan pada KPP DKI Jakarta khususnya jakarta pusat". www.wordpress.com. Diunduh Senin 26 Maret 2012 pukul 11.26 WIB.

Sugiyono, 2008. Metode Penelitian Pendidikan (Pendekatan Kuantitatif, Kualitataif, dan R\&D). Bandung: Penerbit Alfabeta

Suwandhi, 2010. “ Persepsi Wajib Pajak Orang Pribadi atas Pelaksanaan Self Asessment System dalam Keterkaitannya dengan Tindakan Tax Evasion" pada KPP Pratama Bandung Cibeunying. www/html/alumni/core/coms/libs/strin g/friendly.php on line 95. Diunduh Minggu 3 Juni 2012 pukul 20.15 WIB

Tarjo, Indra Kusumawati, 2005. "Analisis Perilaku Wajib Pajak Orang Pribadi Terhadap Pelaksanaan Self Asessment System (Studi di Bangkalan)".
Simposium Riset EKONOMI II, Surabaya 23-24 November 2005. Diunduh Minggu 3 Juni 2012 pukul 20.11 WIB

Udayana, 2008. Pelatihan Statistik dengan SPSS for windows 17.00.

Wahyu Suminarsasi\&Supriyadi, 2010. " Pengaruh Keadilan, Sistem Perpajakan, dan Diskriminasi Terhadap Persepsi Wajib Pajak Mengenai Etika Penggelapan Pajak (Tax Evasion)". Diunduh Senin 7 Januari 2013 Pukul 19.00 WIB. Universitas Gadjah Mada.

Wahyu Widhiarso, 2010. "Pengembangan skala psikologi:Lima kategori respons ataukah empat kategori respons? ". Respon alternatif tengah pada skala likert. Fakultas Psikologi Universitas Gadjah Mada. Diunduh Jumat 15 Februari 2013 pukul 17.40 WIB

Wanda Latuperissa, 2009. "Pengaruh persepsi wajib pajak orang pribadi atas pengenaan sanksi perpajakan terhadap meminimalisasikan tindakan tax evasion pada Kantor Pelayanan Pajak

pada selasa 22 Januari 2013 pukul 10.36 WIB

Zulganef, 2008. Metode Penelitian Sosial \& Bisnis, edisi pertama. Yogyakarta: Penerbit Graha Ilmu. 